\title{
ANALYSIS OF THE RELIABILITY OF THE LEE CLASSIFICATION FOR LUMBAR DISC HERNIATIONS
}

\author{
ANÁLISE DA CONFIABILIDADE DA CLASSIFICAÇÃO DE LEE PARA HÉRNIAS DE \\ DISCOS LOMBARES
}

\section{ANÁLISIS DE LA CONFIABILIDAD DE LA CLASIFICACIÓN DE LEE PARA HERNIAS DE DISCOS LUMBARES}

\author{
Luan Celso Gonçalves, ${ }^{1}$ Alberto Ofenhejm Gotfryd, ${ }^{1}$ Maria Fernanda Silber Caffaro, ${ }^{1}$ Nelson Astur, ${ }^{1}$ Rodrigo Goes Medéa de Mendonça, \\ Mariana Kel TOMa, ${ }^{1}$ Robert MeVES ${ }^{1}$ \\ 1. Irmandade da Santa Casa de Misericórdia De São Paulo, São Paulo, SP, Brazil.
}

\begin{abstract}
Objective: To evaluate the intra- and interobserver reliability of the Lee et al. classification for migrated lumbar disc herniations. Methods: In 2018, Ahn Y. et al. demonstrated the accuracy of this classification for radiologists. However, magnetic resonance images are often interpreted by orthopedists. Thus, a cross-sectional study was conducted by evaluating the magnetic resonance images of 82 patients diagnosed with lumbar disc herniation. The images were evaluated by 4 physicians, 3 of whom were spinal orthopedic specialists and 1 of whom was a radiologist. The intra- and interobserver analysis was conducted using the percentage of concordance and the Kappa method. Results: The report of the classifications used by the four observers had a higher proportion of "zone 3" and "zone 4" type classifications in both evaluation moments. The most affected anatomical levels were L5-S1 (48.2\%) and L4-L5 (41.4\%). The intra- and interobserver concordance, when comparing both moments evaluation of the complementary examinations of the participants involved, was classified as moderate and very good. Conclusions: Lee's classification presented moderate to very good intra- and interobserver reliability for the evaluation of migrated lumbar disc herniation. Level of evidence II; Retrospective Study.
\end{abstract}

Keywords: Lumbosacral Region; Intervertebral Disc Displacement; Magnetic Resonance Spectroscopy; Lumbar Vertebrae.

\section{RESUMO}

Objetivo: Avaliar a confiabilidade intra e interobsenador da classificação de Lee et al. para hérnias migradas de disco lombar. Métodos: Ahn Y et al., em 2018, demonstraram a acurácia dessa classificação para radiologistas. Entretanto, as imagens de ressonância magnética são muitas vezes interpretadas por ortopedistas. Sendo assim, foi realizado um estudo transversal por meio da avaliação de exames de ressonância magnética de 82 casos diagnosticados com hérnia de disco lombar. As imagens foram avaliadas por quatro médicos, sendo três ortopedistas especialistas em cirurgia da coluna e um radiologista. Foi realizada a análise de confiabilidade intra e interobservador com o uso de porcentagem de concordância e do método Kappa. Resultados: A relação das classificações utilizadas pelos quatro avaliadores tiveram, em sua maior proporção, as classificações tipo "zona 3" e "zona 4" em ambos os momentos de avaliação. Os níveis anatômicos mais acometidos foram L5-S1 (48,8\%) e L4-L5 (41,4\%). A concordância intra e interobservador, que comparou os dois momentos de avaliação dos exames complementares dos participantes envolvidos, obteve classificações de moderada a muito boa. Conclusões: A classificação de Lee apresentou confiabilidade intra e interobsenador moderada a muito boa para a avaliação de hérnia migrada de disco lombar. Nível de evidência II; Estudo Retrospectivo.

Descritores: Região Lombossacral; Deslocamento do Disco Intervertebral; Espectroscopia de Ressonância Magnética; Vértebras Lombares.

\section{RESUMEN}

Objetivo: Evaluar la confiabilidad intra e interobservador de la clasificación de Lee et al. para hernias migradas de disco lumbar. Métodos: Ahn Y et al. en 2018, demostraron la exactitud de esa clasificación para los radiólogos. Entretanto, las imágenes de resonancia magnética son a menudo interpretadas por ortopedistas. Siendo así, fue realizado un estudio transversal a través de la evaluación de exámenes de resonancia magnética de 82 casos diagnosticados con hernia de disco lumbar. Las imágenes fueron evaluadas por cuatro médicos, siendo tres ortopedistas especialistas en cirugía de la columna y un radiólogo. Se realizó el análisis de confiabilidad intra e interobservador con el uso de porcentaje de concordancia y Método Kappa. Resultados: La relación de las clasificaciones utilizadas por los cuatro evaluadores tuvieron, en su mayor proporción, las clasificaciones tipo "zona 3" y "zona 4" en ambos momentos de evaluación. Los niveles anatómicos más acometidos fueron L5-S1 (48,8\%) y L4-L5 (41,4\%). La concordancia intra e interobservador, que comparó los dos momentos de evaluación de los exámenes complementarios de los participantes involucrados, obtuvo clasificaciones de moderada a muy buena. Conclusiones: La clasificación de Lee presentó confiabilidad intra e interobservador moderada a muy buena para la evaluación de hernia migrada discal lumbar. Nivel de evidencia II; Estudio Retrospectivo.

Descriptores: Región Lumbosacra; Desplazamiento del Disco Intervertebral; Espectroscopía de Ressonancia Magnetica; Vértebras Lumbares. 


\section{INTRODUCTION}

Disc herniations are displacements of intervertebral disc material beyond the physiological margins of the intervertebral space and are characterized in the axial plane as protrusions or extrusions. The types of herniation are defined based on the distance from the height of the herniation in relation to the base. If a portion of the extruded disc moves away from the external annulus fibrosus it is called disc migration. ${ }^{1,2}$ Sequestrated disc or free disc fragment is the term used in cases where the herniated fragment has no continuity with the rest of the disc. ${ }^{3}$

Percutaneous endoscopic lumbar discectomy (PELD) is a minimally invasive, video-assisted surgical procedure for removal of the herniated disc fragment that has been gaining in popularity. Despite the advantages it offers over the traditional discectomy technique, such as low surgical morbidity, lower rate of postoperative pain, and shorter hospital stay, ${ }^{4}$ the procedure has a relatively long learning curve. ${ }^{5}$ In addition, the accurate positioning of the endoscope at the time of surgery is dependent on the exact assessment of the location of the herniated disc fragment. In this context, the classification proposed by Lee et al. in 2007 has been used to determine the degree of migration of the herniated disc fragment and helps to determine the possibility of endoscopic resection of the herniation.

In 2018, Ahn Y et al. demonstrated the accuracy of this classification for radiologists, however, magnetic resonance images are often interpreted by orthopedists. Thus, the objective of the present study was to evaluate the intra- and interobserver reliability of the Lee et al. classification, ${ }^{1}$ used to assess the degree of lumbar disc herniation migration.

\section{METHODS}

A retrospective cross-sectional study was conducted by evaluating the magnetic resonance image examinations of 82 cases diagnosed with lumbar disc herniation from files stored in the PACS system (Communication and Image Archival System) of the referenced teaching and research institution. The Institutional Review Board of the teaching institution authorized an exemption from the Informed Consent Form since the patients had not undergone any intervention and no personal data would be disclosed during evaluation of the magnetic resonance images. Magnetic resonance was performed using a 1.5 Tesla scanner (Signa, GE, Milwaukee) and only T2-weighted sagittal cuts were used for the analyses.

The migrated disc herniations were classified according to the classification proposed by Lee et al. (Table 1) (Figure 1) The images were evaluated by four physicians, three of whom are orthopedists specialized in spine surgery and one who is a radiologist. (Figure 2)

The classification was available to the evaluators for reference during the entire process. The four evaluators repeated the evaluation using the same images three months after the first evaluation. The confidentiality of all the images and participating patient identification data was respected.

The inclusion criteria considered for this study were men and women of all ages with a diagnosis of lumbar disc herniation admitted to a tertiary hospital during the period from 2016 through 2018. The diagnosis was made by means of magnetic resonance images performed at the respective institution. Patients with previous lumbar

Table 1. Lee's radiological classification for migrated disc herniations.

\begin{tabular}{c|c|c}
\hline Zone & Direction & Distance \\
\hline Zone 1 & Far-Upward & $\begin{array}{l}\text { From the lower margin of the upper pedicle to 3 } \\
\mathrm{mm} \text { from the lower margin of the upper pedicle. }\end{array}$ \\
\hline Zone 2 & Near-Upward & $\begin{array}{r}\text { From 3 mm below the lower margin of the } \\
\text { upper pedicle to the lower margin of the upper } \\
\text { vertebral body. }\end{array}$ \\
\hline Zone 3 & Near-Downward & $\begin{array}{r}\text { From the upper margin of the lower vertebral } \\
\text { body to the center of the lower pedicle. }\end{array}$ \\
\hline Zone 4 & Far-Downward & $\begin{array}{r}\text { From the center to the lower margin of the lower } \\
\text { pedicle. }\end{array}$ \\
\hline
\end{tabular}

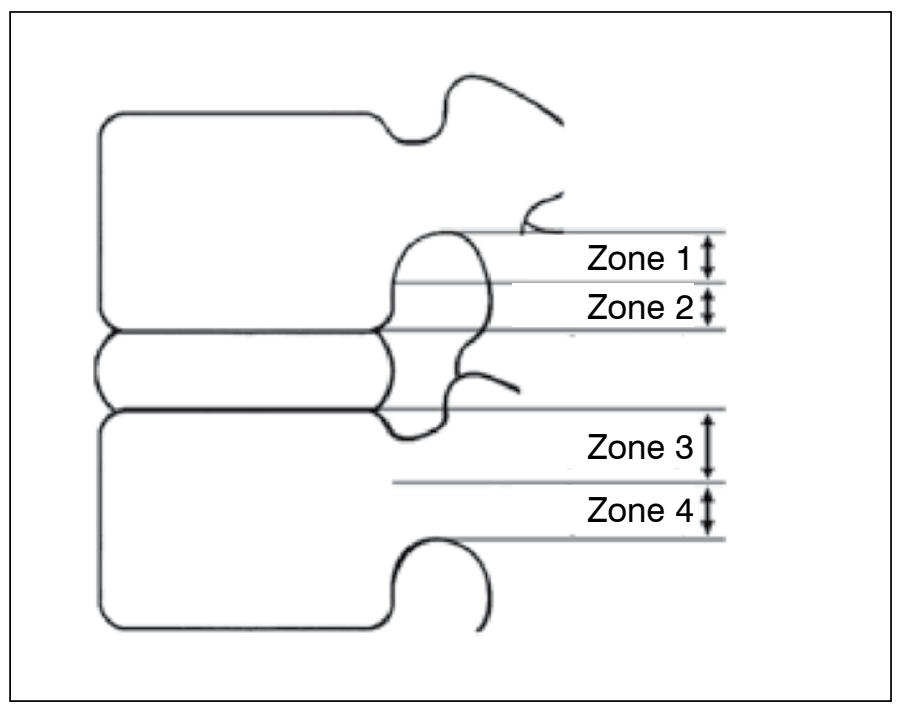

Figure 1. Lumbar herniation displacement regions classified into 4 zones.

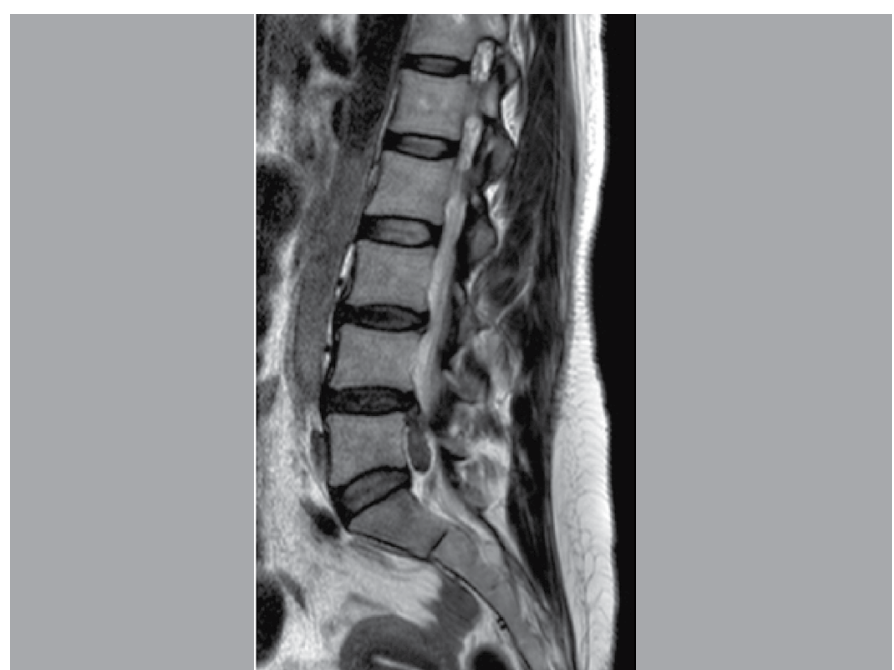

Figure 2. Example of T2-weighted magnetic resonance sagittal cut with migrated lumbar herniation, Zone 4.

spine surgery or who had any other disease of the segment being analyzed were excluded.

The intra- and interobserver reliability of the magnetic resonance evaluations were calculated for data analysis using percentages of concordance and kappa statistics. According to Landis and Koch, a kappa value from 0 to 0.2 indicates weak concordance, from 0.21 to 0.4 indicates fair concordance, from 0.41 to 0.6 indicates moderate concordance, from 0.61 to 0.8 indicates strong concordance, and from 0.81 to 1 indicates almost perfect concordance. ${ }^{6}$ Data analyses were conducted using SPSS Statistics 21 statistical software.

The sample calculation was performed using $R$ statistical software (Project for Statistical Computing) as the confidence interval for inter-observer evaluations with four observers. The values involving the lower and upper limits were 0.6 and 0.8 , respectively, totaling a sample calculation of 82 cases.

The present study was approved by the Institutional Review Board of the institution where it was developed as opinion 2.283.507.

\section{RESULTS}

Of the 82 participants, 44 (54\%) were men and 38 (46\%) were women, with a mean age of 45 years. The lumbar level with the highest frequency of disc herniation was L5-S1 (48.8\%), followed by L4-L5 $(41.4 \%)$. As regards the treatment used, 63 participants were submitted to surgery and 19 underwent conservative treatment. (Table 2) 
The list of classifications used by all four evaluators can be seen in Table 3. According to the classification, the most common herniated disc fragment migration locations were zones 3 and 4 in both evaluation moments. (Figure 3)

In the comparison of the two evaluation moments of the complementary examinations of the participants involved by means of the kappa coefficient, the level of intraobserver concordance was "moderate" for observer 1 ( $k$ : $0.45 ; p<0.05)$, "good" for observer 2 ( $k: 0.61 ; p<0.05)$, and "very good" for both observers 3 ( $k: 1.00$; $p<0.05)$ and $4(k: 0.98 ; p<0.05)$. (Table 4$)$

When we evaluated the interobserver relationship observed in the first moment, we saw better levels of concordance between observers 3 and 4 ( $k: 1.00 ; p<0.05)$, followed by the comparison between the observers 2 and $3(k: 0.53 ; p<0.05)$ and observers 2 and $4(k: 0.53 ; p<0.05)$. (Table 5$)$ In the same evaluation, but related to the second moment, the levels of concordance between observers 3 and 4 again showed the most positive results ( $k$ : 1.00; $p<0.05)$, followed by the concordance between observers 1 and 4 ( $k: 0.61 ; p<0.05)$. (Table 6)

Table 2. Clinical and demographic data of patients with lumbar disc herniation.

\begin{tabular}{c|c|c}
\hline \multicolumn{2}{c|}{ Variables } & No. \\
\hline \multirow{2}{*}{ Individuals } & $\mathbf{8 2}$ \\
\hline \multirow{2}{*}{ Agex } & Male & $38(46.0 \%)$ \\
\cline { 2 - 3 } & Female & $44(54.0 \%)$ \\
\hline \multirow{4}{*}{ Lumbar Herniation Level } & L1-L2 & $45.0 \pm 10.2$ \\
\cline { 2 - 3 } & L2-L3 & 0 \\
\cline { 2 - 3 } & L3-L4 & $7(1.2 \%)$ \\
\cline { 2 - 3 } & L4-L5 & $34(4.6 \%)$ \\
\hline Treatment & L5-S1 & $40(48.8 \%)$ \\
\hline & Surgical & $63(76.8 \%)$ \\
\hline
\end{tabular}

Table 3. Distribution of lumbar disc herniation by observer.

\begin{tabular}{c|c|c|c|c|c|c|c}
\hline Observer & Moment & $\begin{array}{c}\text { Not } \\
\text { Migrated }\end{array}$ & Zone 1 & Zone 2 & Zone 3 & Zone 4 & Total \\
\hline \multirow{2}{*}{1} & 1 & 18 & 7 & 11 & 28 & 18 & 82 \\
\cline { 2 - 8 } & 2 & 3 & 7 & 16 & 47 & 9 & 82 \\
\hline \multirow{2}{*}{2} & 1 & 8 & 15 & 10 & 31 & 18 & 82 \\
\cline { 2 - 8 } & 2 & 8 & 8 & 17 & 32 & 17 & 82 \\
\hline \multirow{2}{*}{3} & 1 & 0 & 8 & 16 & 39 & 19 & 82 \\
\cline { 2 - 9 } & 2 & 0 & 8 & 16 & 39 & 19 & 82 \\
\hline \multirow{2}{*}{4} & 1 & 0 & 8 & 16 & 39 & 19 & 82 \\
\cline { 2 - 9 } & 2 & 0 & 9 & 15 & 39 & 19 & 82 \\
\hline \multicolumn{2}{c|}{ Total } & 37 & 70 & 117 & 294 & 138 & 656 \\
\hline \multicolumn{2}{c|}{$\%$} & 5.6 & 10.7 & 18.0 & 44.8 & 21.0 & \\
\hline
\end{tabular}

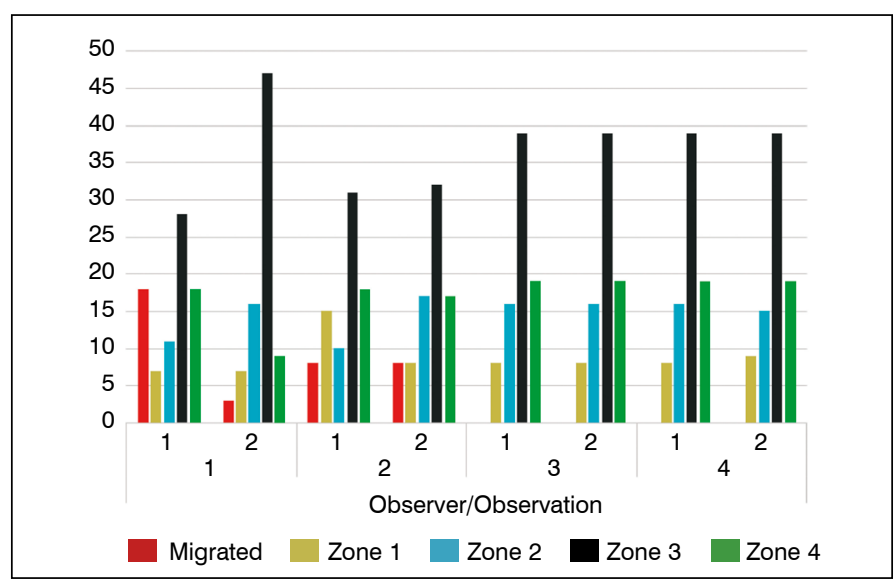

Figure 3. Frequency of the classifications of both moments for each evaluator.
Table 4. Intraobserver concordance in evaluation 1 vs. evaluation 2.

\begin{tabular}{c|c|c}
\hline Observers & k (Significance) & Level of Concordance \\
\hline 1 & $0.45(0.01)$ & Moderate \\
\hline 2 & $0.61(0.01)$ & Good \\
\hline 3 & $1.00(0.01)$ & Very Good \\
\hline 4 & $0.98(0.01)$ & Very Good \\
\hline
\end{tabular}

Level of Significance: $k>0.80$ (Very Good), $0.80 \geq k>0.60$ (Good), $0.60 \geq k>0.40$ (Moderate), $0.40 \geq k>0.20$ (Fair), $k \leq 0.20$ (Poor).

Table 6. Interobserver concordance for evaluation 2.

\begin{tabular}{c|c|c}
\hline Observers & k (Significance) & Level of Concordance \\
\hline 1 Vs. 2 & $0.51(0.01)$ & Moderate \\
\hline 1 Vs. 3 & $0.59(0.01)$ & Moderate \\
\hline 1 Vs. 4 & $0.61(0.01)$ & Good \\
\hline 2 Vs. 3 & $0.57(0.01)$ & Moderate \\
\hline 2 Vs. 4 & $0.59(0.01)$ & Moderate \\
\hline 3 Vs. 4 & $0.98(0.01)$ & Very Good \\
\hline
\end{tabular}

Level of Significance: $k>0.80$ (Very Good), $0.80 \geq k>0.60$ (Good), $0.60 \geq k>0.40$ (Moderate), $0.40 \geq k>0.20$ (Fair), $k \leq 0.20$ (Poor).

Table 5. Interobserver concordance for evaluation 1.

\begin{tabular}{c|c|c}
\hline Observers & k (Significance) & Level of Concordance \\
\hline 1 Vs. 2 & $0.49(0.01)$ & Moderate \\
\hline 1 Vs. 3 & $0.48(0.01)$ & Moderate \\
\hline 1 Vs. 4 & $0.48(0.01)$ & Moderate \\
\hline 2 Vs. 3 & $0.53(0.01)$ & Moderate \\
\hline 2 Vs. 4 & $0.53(0.01)$ & Moderate \\
\hline 3 Vs. 4 & $1.00(0.01)$ & Very Good \\
\hline
\end{tabular}

Level of Significance: $k>0.80$ (Very Good), $0.80 \geq k>0.60$ (Good), $0.60 \geq k>0.40$ (Moderate), $0.40 \geq k>0.20$ (Fair), $k \leq 0.20$ (Poor).

\section{DISCUSSION}

This study used a classification proposed by South Korean researchers more than a decade ago and tested its reliability and reproducibility in Brazilian patients.

A study similar to the one developed, modified and evaluated the reliability and the functionality of the classification described for migrated lumbar disc herniation. The study used two radiologists to classify the migrations and showed that it is reliable and reproducible and may be useful in evaluating clinical manifestations and treatment outcomes. ${ }^{7}$

The present study used a more heterogeneous evaluation, performed by three orthopedists and a radiologist, and obtained similar concordance results (from moderate to very good), demonstrating the equal ability of both types of professionals to interpret and use the classification. Thus, the classification evaluated proved to be useful and reproducible, essential qualities of a good classification system.

In relation to anatomical location, there was a predominance of disc migration in the lower lumbar levels (L5/S1 and L4/L5). According to the literature, around $95 \%$ of disc herniations in people from 25 to 55 years of age occur in the lower lumbar spine (levels L4/L5 and L5/S1), while disc herniations above this level are more common in people above 55 years of age. ${ }^{7}$ In two other studies of surgeries for sciatica, at least $95 \%$ of the herniated discs were in levels L4/L5 and L5/S1.8,9

A higher incidence of lower level lumbar herniations, classified as zones 3 and 4 in this study, may have been related to the mean age being below 50 years, as studies have related higher-level migrations to elderly patients. There are some theories for such a migration pattern in the elderly, such as the L2/L3 extradural space becoming widely patent and the adipose tissue diminished with the advancing age and more sedentary lifestyle of the elderly, in addition to the increased compressive effect of the structures that surround the lower lumbar region in the sitting or lying position. In young people, there is an attenuated gravitational effect on the herniated material, leading to lower migrations. ${ }^{10}$

Some limitations of the classification were found during this 
concordance study. There was some difficulty with downward migrated herniations at the L5-S1 level due to the anatomical characteristics of the S1 pedicle, which does not follow the proposed classification. Because of the considerable frequency of herniations in L5-S1, this difficulty became relevant.

Another limitation would be the classification of levels with coexisting proximal and distal migrations, as the choice of which to evaluate would be at the discretion of the observer, thus causing negative bias of concordance in the classification.

\section{CONCLUSION}

The disc herniation classification proposed by Lee et al. demonstrated adequate intra- and interobserver reliability for the evaluation of migrated lumbar disc herniation.

All authors declare no potential conflict of interest related to this article.

CONTRIBUTION OF THE AUTHORS: Each author made significant individual contributions to this manuscript. RM, MFSC, AOG, NA, RGMM, MKT, and LCG participated in the discussion of the results and contributed to the review and final version of the study. LCG, AOG, NA, and MKT participated actively in the data collection for this study.

\section{REFERENCES}

1. Lee S, Kim SK, Lee SH, Kim WJ, Choi WC, Choi G, et al. Percutaneous endoscopic lumbar discectomy for migrated disc herniation: classification of disc migration and surgical approaches. Eur Spine J. 2007:16(3):431-7.

2. Buckwalter JA. Aging and degeneration of the human intervertebral disc. Spine (Phila Pa 1976). 1995;20(11):1307-14.

3. Pfirmann CW, Resnick D. Schmorl nodes of the thoracic and lumbar spine: radiographic-pathologic study of prevalence, characterization, and correlation with degenerative changes of 1,650 spinal levels in 100 cadavers. Radiology. 2001;219(2):368-74.

4. Choi KC, Lee DC, Shim HK, Shin SH, Park CK. A strategy of percutaneous endoscopic lumbar discectomy for migrated disc herniation. World Neurosurg. 2017;99:259-66.

5. Hsu HT, Chang SJ, Yang SS, Chai CL. Learning curve of full-endoscopic lumbar discectomy. Eur Spine J. 2013;22(4):727-33.
6. Landis JR, Koch GG. The measurement of observer agreement for categorical data. Biometrics. 1977;33(1):159-74

7. Ahn Y, Jeong TS, Lim T, Jeon J. Grading system for migrated lumbar disc herniation on sagittal magnetic resonance imaging: an agreement study. Neuroradiology. 2018;60(1):101-7.

8. Peul WC, Van Houwelingen HC, van den Hout WB, Brand R, Eekhof JA, Tans JT, et al. Surgery versus prolonged conservative treatment for sciatica. N Engl J Med. 2007;356(22):2245-56.

9. Weinstein JN, Tosteson TD, Lurie JD, Tosteson AN, Hanscom B, Skinner JS, et al. Surgical vs nonoperative treatment for lumbar disk herniation: the Spine Patient Outcomes Research Trial (SPORT): a randomized trial. JAMA. 2006;296(20):2441-50.

10. Daghighi MH, Pouriesa M, Maleki M. Fouladi DF, Pezeshki MZ, Khameneh RM, et al. Migration patterns of herniated disc fragments: a study on 1,020 patients with extruded lumbar disc herniation. Spine J. 2014;14(9):1970-7. 